\title{
Karlovy Vary 2008
}

\author{
By Ron Holloway \\ Fall 2008 Issue of KINEMA
}

\section{KARLOVY VARY INTERNATIONAL FILM FESTIVAL 2008}

\section{A Festival for Independents}

One glance at the line-ups of the top A-category competition film festivals, and you can rate and measure even criticize - them for their respective portfolios carried proudly on their backs. Cannes is honoured as an authentic "auteur festival," respected each May for discovering new directorial talent while furthering the careers of past auteur directors even when they are evidently over the hill. Venice, praised as a "director's haven," scores among veteran festivaliers as a laid-back September rendezvous for cult directors at the end of summer, a must for cineastes. Berlin likes to promote its "Hollywood image," using its February dates to book as many box-office hits of the previous Christmas season as slots will allow, knowing full well that LA producers easily benefit from a Berlinale festival launch before their films hit the lucrative German screens.

So what is Karlovy Vary best known for? Scheduled in early July, the $43^{\text {rd }}$ Karlovy Vary International Film Festival (4-12 July 2008), under the dual leadership of Jií Bartoška (president) and Eva Zaoralová (artistic director), has developed in recent years into a unique "platform for independents," a summer festival in a renown spa that is particularly proud of its links to Sundance and Tribeca in the United States, Sochi in Russia, and Pusan in Korea. Indeed, for young Czech and Slovak backpackers pilgering annually to KVIFF, the core of the festival fare has always been the popular Forum of Independents section, programmed for over a decade by Stefan Ulrik, a Czech TV reporter. Ulrik also gained some renown as a founding member of the roving "Festival Band" - aka "Three Stefan" (Stefan Ulrik of Karlovy Vary, Stefan Kitanov of Sofia, Stefan Laudyn of Warsaw ) - whose annual concerts at Karlovy Vary run into the wee hours of the morning. This year was no exception.

One glance at past Crystal Globe (KVIFF's Grand Prix) winners also underscores how valuable the Forum of Independents has been to the festival image. In 2006, Karlovy Vary hit pay dirt by inviting the Sundance Film Festival to present award winners, both features and documentaries, from its festival archive. This tip-of-thehat paid off on awards night, when Laurie Collyer's Sherrybaby (USA), the hit of the Sundance festival that January, was awarded the Crystal Globe, while the film's lead actress, Maggie Gyllenhaal, received the prize for Best Actress. As much heart-rending melodrama as hard-hitting documentary, Sherrybaby chronicled the efforts of a young mother to win back the affections of her little daughter upon being released from prison for drug abuse.

This year, KVIFF invited Amy Redford to present her debut feature The Guitar (USA) in the competition. The story of a young woman coming to grips with terminal cancer by teaching herself to play on the electric guitar, The Guitar had premiered last January at Sundance, the festival founded by her father Robert Redford. A hit at Sundance, the film features a standout performance by Saffran Burrows as the afflicted woman who discovers a strength she barely knew she could draw upon.

\section{Tact and Taste}

Ask visiting independent directors why they prefer Karlovy Vary, and the response usually boils down to two indefinable elements that allows this festival to stand head and shoulders over many of its competitors. "Tact and taste," as one Karlovy Vary insider put it. The Karlovy Vary website - www.kviff.com - tells most of the story.

Packed with everything relevant from a photo gallery to a play video, from its Festival Daily (in Czech and English) to statistical information (10,872 accredited participants, 143,781 tickets sold, 477 screenings), it even has slots for hot tips and registration for its website newsletter. Altogether, 29 festival guests are listed on the website, each spotlighted with career details to help gun-slinging bloggers to keep the record straight. Among this year's honoured Yankee guests were Robert De Niro (Barry Levinson's What Just Happened), Les Blank (five-documentary retrospective tribute), Paul Mazursky (Bob $\mathscr{E}$ Carol $\mathscr{G}$ Ted $\mathscr{G}$ Alice, 1969 New 
Hollywood classic), John Sayles (Honeydripper), Tom McCarthy (The Visitor), Danny Glover and Melonie Diaz (both in Michel Gondry's Be Kind Rewind). Something like a roll-call of American Indies.

Complementing the website, and just as important for cineastes and historians, the $43^{\text {rd }}$ KVIFF catalogue, running 328 pages, offers accurate information on films and directors invited to the festival, focusing in particular on biographies of independent directors who have visited Karlovy Vary in the past. Thanks to a team of perceptive scouts, Karlovy Vary has boosted its image abroad as a festival set on discovering talent at its source.

Julietta Sichel, KVIFF program director, is a regular visitor each October at the Pusan Film Festival, deemed by many festivaliers as the world's top showcase of Asian cinema. This year, she brought back from Pusan Kim Byung-woo's Written (Korea). A film within a film within a film, Written plumbs the intellectual depths of screen writing by having a film character confront the actor selected to play him in the preproduction stage. Programmed in the Forum of Independents, it was awarded the Netpac (Network for Promotion of Asian Cinema) Prize.

Awarded the runner-up Special Jury Prize in the KVIFF competition, Nan Treveni Achnas's The Photograph (Indonesia) was six years in the making from project to release - finally brought to completion thanks to co-production partners in France, Netherlands, Switzerland, and Sweden. The story of an aged Jakarta photographer who befriends a young prostitute, his family secret is gradually revealed to the unexpected guest via antiquated photographs harbored in the old man's studio. A talented woman director in Indonesian cinema, Nan Treveni Achnas's Pasir berbisik (Whispering Sands, Indonesia-Japan, 2001) had previously been invited to the $2002 \mathrm{KVIFF}$ in the Another View section. The story of an impoverished Indonesian family trying to survive as refugees on a desert landscape, Whispering Sands established Achnas as a director with an affinity for the plight of outsiders.

KVIFF scout Galina Kopaneva regularly visits the Sochi Open Russian Film Festival. Among the half-dozen Sochi films booked this year by Karlovy Vary was Alexei Uchitel's Plennyj (Captive), programmed in the competition and awarded Best Director. Captive scores as a rarity in Russian cinema: a forthright inquiry into the pain inflicted by the Russian military upon innocent bystanders during the Chechen war. When a young villager is enlisted by trapped Russian soldiers in a mountainous terrain to help lead the convoy to safety, two soldiers, a hardened veteran and a young recruit, accompany the young man through the lines. The trio gradually confront their own misgivings in a conflict they barely understand.

The prestigious East of the West Prize, awarded by a separate international jury to the best film from Central and Eastern European countries, went to Sergei Dvortsevoy's Tulpan (Kazakhstan), a co-production with Russia, Poland, Germany, and Switzerland. Set in the steppes of Kazakhstan, Tulpan confirms Sergei Dvortsevoy as an adept film poet, a director who draws his inspiration from simple situations in real life. Preferring nonprofessionals over actors, he is able to create a world of laughter and tears that anyone in the audience can relate to.

Tulpan, whose face we never see in the film, is courted by Asa, who has just returned as a self-styled hero in the naval military and now seeks independence as a shepherd with his own yurt. The courtship is stymied, however, when the suitor learns that his ears happen to be too big - yet, as it turns out, there are other ways to prove his manhood. Awarded the Un Certain Regard Prize at Cannes, Tulpan was also voted a share of the Netpac Prize at Karlovy Vary. Thanks to this remarkable feature film debut, Sergei Dvortsevoy already ranks as a leading independent director in Central Asia.

\section{Czech Independents}

Czech Independents also benefited from KVIFF largesse. In 2002, the Crystal Globe was awarded to the Czech entry that had opened the festival: Petr Zelenka's lively mock-documentary Rok dábla (The Year of the Devil), a fake account of a popular rock singer-songwriter with his band on a make-believe tour across the country as funeral musicians. A gifted playwright as well as innovative filmmaker, Petr Zelenka is one of the key figures in the current (second) Czech new wave of independent filmmakers that began in the mid-1990s and continues unabated until the present day. Known across the breath of eastern Europe, his play Příběhy obyčejného šilenství (Tales of Common Insanity) - adapted to the screen under the English title Wrong Side $U p(2005)$ - ran for a year in a Prague theatre and was a stage hit as well in Slovakia, Hungary, and Slovenia. 
Zelenka returned to Karlovy Vary this year with Karamazovi (The Karamazovs), a screen version of the classic stage adaptation of Dostoevsky's novel The Brothers Karamazov by the late writer-director Evald Schorm (1931-1988), an uncompromising leader of the first Czech new wave of the 1960s. Staged in Poland in the rundown Nova Huta steel mill near Cracow, and conceived within the context of rehearsals for a performance at an alternative drama festival, The Karamazovs features Zelenka's own stage ensemble in a production that mirrors Dostoevsky's moral conflicts among the actors themselves and ends on a tragic note among the steelmill spectators. Awarded the FIPRESCI Critics Prize, The Karamazovs deserved more. For my taste, it was the one memorable film in the competition that deserves an extended life on the festival circuit and in arthouse release.

Michaela Pavlátová's Dĕti noci (Night Owls), the other Czech film in the competition, is set during the night shift at a 24-hour convenience store. It features a couple of neighbourhood oddballs in absurd situations rather common to the Karlín district in Prague. Although burdened by a thin scenario, the smattering of quaint gags in Night Owls did merit for Marta Issová and Jiří Mádl back-to-back awards for Best Actors. Ofka (Marta Issová) is not quite sure if she's ready to leave childhood to grow up. Her boyfriend Ubr (Jiří Mádl), her street companion with a fascination for garbage cans, is hopelessly in love with her. That's about it, plot-wise. Better known as a Czech animation director, Michaela Pavlátová's Řeči, řeči, řeči (Words, Words, Words, 1999) received an Oscar Nomination. From there she moved on to documentary filmmaking and is now a feature film talent worth keeping an eye on.

Another standout in the Czech Films 2007-2008 series, Pavel Koutecký and Miroslav Janek's Občan Havel (Citizen Havel) is one of those documentaries you want to see over again from the beginning. Compressed into a two-hour straightjacket, Citizen Havel is remarkable in many respects. An intimate, revealing, urbane documentary portrait of writer-playwright-politician Václav Havel, the tenth and last President of Czechoslovakia (1989-1992) and the first President of the Czech Republic (1993-2003), the film was only possible due to a close friendship with documentary filmmaker Pavel Koutecký (1956-2006), who unfortunately died in a tragic accident before the film was edited. Completed in the post-production stage by colleague Miroslav Janek, Citizen Havel covers the period from 1992, when Václav Havel was weighing his chances for a second presidential term, and ends in 2006, when circa 120 hours had already been shot on the life and times of the Czech Republic's first citizen.

Citizen Havel offers the viewer many insights into how the second-term president successfully outmanoeuvered his parliamentary opponent, Václav Klaus (today the Czech president). Scenes from parliamentary headknocking are interspersed to add to the drama. Also, we visibly feel how his warm relationship with his first wife, Olga (1933-1996), who died of cancer, was then carried over to his second wife, Dagmar. Indeed, the women in Havel's life play a key supportive role in his decision-making. Lastly, there are the prominent visitors who walk in and out of his open-door office: among others, Bill Clinton, Jacques Chirac, Madeleine Albright, and the Rolling Stones, in addition to Czech and Slovak politicians and personalities. One scene underscores the easy-going atmosphere of the job. When Mick Jagger asks about a good restaurant, Václav Havel obliges him with private tip.

\section{Film Noir}

The Crystal Globe was awarded to Henrik Ruben Genz's Frygtelig lykkelig (Terribly Happy, Denmark). Partly film noir, partly black comedy, with grotesque elements of the psycho-thriller and the lawless Western thrown in on the side, Terribly Happy comes across as a homage to American independent cinema. Based on a popular detective novel by Erling Jepsen with the same title, the twists in the story about a Copenhagen policeman punished with a disciplinary assignment to a provincial outpost are what make it a winner. Here in South Jutland, its landscape shot in eye-catching widescreen, the local gentry prefer vigilante justice over law by the book. So when a distressed woman seeks police help from her abusive husband, secrets come out of the closet, and the ensuing affair leads to grotesque encounters and the eventual showdown - in a bar, no less.

A homage to David Lynch and the Coen Brothers? Or a tip of the hat to a similar cynical hard-boiled detective tale - Three of a Kind by James M. Cain - adapted to the screen by Raymond Chandler into Double Indemnity (1944), directed by Billy Wilder? Probably both.

For CentEast filmmakers are currently borrowing freely from American film noir classics. The name Philip 
Marlowe, Raymond Chandler's alter ego, also pops up as an inside joke in Attila Gigor's A nyomozo (The Investigator, Hungary-Sweden-Ireland), awarded the FICC Film Clubs Prize. Why Philip Marlowe is easy to understand, but tricky to explain. In Attila Gigor's debut feature The Investigator he leans heavily on film noir aesthetics to tell the story of a 37-year-old coroner, whose conscientious care for his invalid mother (dying of spine cancer) leads him to a contract killing to obtain the money for a possible survival operation in Sweden. However, once the foul deed has been committed, the man discovers that the victim might be his own unknown brother, which then turns the killer into an investigator to find out just who the victim really was in the first place. As a riddle to be unlocked, there's a certain fascination of sitting through the film's twists and turns over the two-hour stretch.

In yet another stab at film noir aesthetics, Alexei Mizgirev's Kremen (The Hard-Hearted, Russia) chronicles the moral downfall of a lad from the provinces, who, fresh out of the military, joins the corrupt police force in Moscow to prove how tough he is. In The Hard-Hearted the lad's love for a girl from his hometown, now a university student, only hardens his feelings when she doesn't return his affections. Similar to Raymond Chandler's hard-boiled detective tales, where the cops are usually numbered among the bad guys, the headstrong youth follows his own code of justice until the chips are finally down and a choice for life has to be made. According to Alexei Mizgirev, The Hard-Hearted mirrors conditions rather closely in today's Moscow police force.

Along the same lines, some CentEast women directors are raising moral questions without offering even a hint of solutions. In Kristina Buozyte's debut feature Kolekcioniere (The Collectress, Lithuania) a traumatized beauty decides to exorcise her aggressions with video experiments leaning towards the excess. With the help of an alcoholic video editor, her extreme behaviour is used to entice and eventually seduce her sister's fiancee. Although an exploitive tale without much rhyme or reason, The Collectress fascinates as a portrait of troubled youth in new Europe. Further, Kristina Buozyte found in Gabija Ryskuviene an attractive femme fatale with ice in her veins.

Also, in Dorota Kedzierzawska's Pora umierac (Time to Die, Poland), a minimalist portrait shot in blackand-white about an old woman living out her last years in a rundown villa, the performance by 91-year-old Danuta Szalfarska, the grand lady of Polish cinema, breathes life into an otherwise typical tale of social disorder. As Time to Die unfolds, we sense the reasons why the woman feels she not all ready to kick the bucket. Strapped with an obese daughter, an goof-ball son, and a brat of a granddaughter, her only thought now is to save her beloved house from an avaricious family scheme and near-do-well neighbours. "Time for mischief-making" might be a better title.

\section{A Reckoning with the Past}

"This year marks the 40th anniversary of a fundamental period in our country's history," stated artistic director Eva Zaoralová in the catalogue for the $43^{\text {rd }}$ KVIFF. "The political trend exemplified by the Prague Spring attempted to make sure that Socialism possessed a 'human face.' We all know how it ended ... they sent in the tanks."

So, this year, to commemorate the $40^{\text {th }}$ anniversary of the Prague Spring, Czech director Ivan Passer (b. 1933) was welcomed back from his American exile to serve as President of the International Jury. To mark the occasion, two of Ivan Passer's classic Prague Spring productions were programmed. Passer's short Fádní odpoledne (A Boring Afternoon, Czechoslovakia, 1964), an adaptation of a Bohumil Hrabal story, is set in a pub on a Sunday afternoon - tongue-in-cheek humour to tickle the funny-bone! And his legendary feature Intimni osvĕtlení (Intimate Lighting) still charms an improvised free-flowing feature about two musicians who meet for a casual weekend in a country cottage - nothing much happens, save that in the course of conversations one comically absurd situation tops another.

In addition, tributes were paid to Slovak directors Juraj Jakubisko and Dušan Hanák (both born in 1938). The tribute to Juraj Jakubisko, a master of "magical realism," was crowned with the world premiere of his long awaited Báthory production, a Slovak co-production with the Czech Republic, Hungary, and Great Britain. Based loosely on the infamous life of Slovak Countess Elisabeth Báthory (1560-1614), who is said to have bathed in the blood of slain virgins to keep her beauty, the three-part, 140-min spectacle stars British actress Anna Friel in the title role. As much colourful fiction as historical fact (Italian painter Caravaggio is thrown in for fictitious pictorial effect), Báthory does have its moments when Jakubisko charges the story 
with some inventive visual gags to comment on the absurdities of an intriguing court.

But what's the point of the film? Was Báthory fighting to save Christian Europe from the invading Turks, while paying lip-service to Protestant and Catholic forces at the height of the Reformation? Who knows... But one thing is certain. Shot in English, with delays that extended the shooting schedule over nearly three years, the budget alone of $\$ 15$ million makes Báthory the most expensive Czech and Slovak production ever made. But too bad Karlovy Vary did not include Jakubisko's legendary Zbehovia a pútnici (Deserters and Fools, Czechoslovakia, 1968), on the absurdities of war games, in the KVIFF tribute.

Dušan Hanák, too, was honoured with a memorable retrospective tribute. Gracing the walls leading to the terrace of the flagship Thermal Hotel was an exhibition of Hanák's insightful photographs of faces and people in Africa and Latin America. Mostly taken after photographer-direction had finally gained permission to leave the country. Programmed in the Dušan Hanák retrospective were two films to remind us of how talented this suppressed filmmaker was at the height of his career.

Hanák's Obrazy starého sveta (Pictures of the Old World, Czechoslovakia, 1972), inspired by the work of Slovak photographer Martin Martinek, portrayed poor old people at the end of their lives. Immediately censored by the Communist government for its "ugly" representation of Slovak reality, Pictures of the Old World barely survived in the national film archives. Today it is ranked among one of the finest Slovak films made. His Růžové sny (Rosy Dreams, Czechoslovakia, 1976), on the surface an innocent tale about a love affair between a gypsy girl and a young postman, underscored at that time the fragile tolerance of gypsies in Slovak society.

Standing ovations greeted Ivan Passer, Juraj Jakubisko, and Dušan Hanák when festival president Jiří Bartoška handed them Crystal Globes for Outstanding Artistic Contribution to World Cinema.

\section{A Personal Footnote}

Want to know what I wrote forty years ago, while attending the 16th Karlovy Vary International Film Festival (5-15 June 1968)? At that time, I was writing for the Film Society Review, a minor New York film publication edited by Bill Starr out of a basement office at the Bleeker Street Cinema in Greenwich Village.

Back then, the Karlovy Vary festival was held in the Grand Salle, the ballroom link between the Pupp Hotel and its adjacent Park Hotel. Overjoyed to participate in the lively atmosphere of the Prague Spring as it played out daily at the festival, I must admit that I wasn't much impressed at the time by the "wry wit" in Jiří Menzel's Rozmarné léto (Capricious Summer, Czechoslovakia, 1967), his screen adaptation of Vladislav Vančura's 1926 novel that was awarded the Crystal Globe. Later, I changed my mind about that bucolic jaunt into the past.

Instead, I wrote with some passion about the "main attraction" at the festival - that Open Forum in the regal Láznĕ I bathhouse.

"The topic: artistic freedom. Or, to put it more precisely: the freedom to think freely. The discussion, for all practical purposes, was narrowed down to an intense dialogue between the Czechs, the Russians, and the East Germans. The outcome was a resolution, drafted by the majority of the delegates, that is something akin to the Bill of Rights. To back up their new-found freedom, the festival officials declared at the closing ceremonies that Karlovy Vary would henceforth operate separately from Moscow (formerly they alternated). The Czechs have an ancient and dignified film history. They want to keep it that way - without interference!" (Film Society Review, Summer, 1968)

Forty years later, the Karlovy Vary International Film Festival is not just a "Platform for Independents" open to all comers. It's also become a vital crossroads between East and West.

\section{References}

\section{Awards}


Crystal Globe - Grand Prix

Frygtelig lykkelig (Terribly Happy, Denmark), dir Henrik Ruben Genz

Special Jury Prize

The Photograph (Indonesia-France-Netherlands-Switzerland-Sweden), dir Nan Triveni Achnas

Best Director

Alexei Uchitel, Plennyj (Captive, Russia-Bulgaria)

Best Actress

Martha Issová, Dĕti noci (Night Owls, Czech Republic), dir Michaela Pavlátová

Best Actor

Jiří Mádl, Děti noci (Night Owls, Czech Republic), dir Michaela Pavlátová

Special Mentions

Karamazovi (The Karamazovs, Czech Republic-Poland), dir Petr Zelenka

A nyomozo (The Investigator, Hungary-Sweden-Ireland), dir Attila Gigor

Documentary Awards

Best Documentary over 30 minutes

Man on Wire (UK), dir James Marsh

Special Jury Mention

Bigger, Stronger, Faster* (USA), dir Christopher Bell

Best Documentary under 30 minutes

Letunt vilag (Lost World, Hungary-Finland), dir Gyula Nemes

East of the West Award

Tulpan (Kazakhstan-Russia-Poland-Germany-Switzerland), dir Sergei Dvortsevoy Special Mention

Shivachki (Seamstresses, Bulgaria), dir Lyudmil Todorov

FIPRESCI (International Critics) Award

Karamazovi (The Karamazovs), Czech Republic-Poland), dir Petr Zelenka

Ecumenical Award

The Photograph (Indonesia-France-Netherlands-Switzerland-Sweden), dir Nan Triveni Achnas

FICC (Film Clubs) Award

A nyomozo (The Investigator, Hungary-Sweden-Ireland), dir Attila Gigor

NETPAC (Network for Promotion of Asian Cinema) Award - ex aequo

Written (South Korea), dir Kim Byung-woo - Forum of Independents

Tulpan (Kazakhstan-Russia-Poland-Germany-Switzerland), dir Sergei Dvortsevoy - East of the West

Independent Camera Award - Forum of Independents

Rusalka (Mermaid, Russia), Anna Melikyan

Europa Cinemas Label

Bahrtalo! - Jo szerencset! (Bahrtalo! - Good Luck!, Hungary-Austria-Germany), dir Róbert Lakatos - East of the West

Právo Audience Award

12 (Russia), dir Nikita Mikhalkov - Out of Competition

Award for Outstanding Artistic Contribution to World Cinema

Robert De Niro (USA)

Dušan Hanák (Slovakia)

Juraj Jakubisko (Slovakia)

Ivan Passer (USA) 


\section{Festival President's Award}

Danny Glover (USA)

Christopher Lee (UK)

Town of Karlovy Vary Award

Armin Mueller-Stahl (Germany)

\section{Author Information}

Ron HOLLOWAY (1933-2009) was an American critic, film historian, filmmaker and correspondent who adopted Europe as his home in the early fifties and spent much of his life in Berlin. He was an expert on the study of German cinema and against all odds produced, with his wife Dorothea, the journal German Film, keeping us up-to-date with the work of directors, producers and writers and the showing of German films around the world.

In 2007, Ron Holloway and his wife were awarded the Berlinale Camera Award. Ron also received the Bundesverdienstkreuz (German Cross of Merit), Polish Rings, Cannes Gold Medaille, the American Cinema Foundation Award, the Diploma for Support of Russian Cinema and an honorary award from the German Film Critics' Association.

Ron was also a valued contributor to Kinema for the past fifteen years. 